\title{
Gravity Model and International Trade: The Case of Western Balkan Countries
}

\author{
Emi Malaj \\ PhD Candidate \\ Elida Liko \\ Associate Professor \\ Visar Malaj (PhD)* \\ Department of Economics \\ Faculty of Economics \\ University of Tirana, Albania
}

\begin{abstract}
The magnitude of international trade flows may be affected by social and cultural variables, such as population structure, common language and colonial links; economic and political variables, such as economic sizes or incomes, trade costs, trade agreements, exchange rate and relative prices; technical variables, such as technology advancement, infrastructure condition and geographical distance; and some more complex variables to be anticipated such as political conflicts, meteorological conditions and natural catastrophes. The main objective of this work is the empirical analysis of the determinants of bilateral trade between Western Balkan countries and the most important partners through the gravity theory. We propose a particular gravity equation for trade, including basic and experimental independent variables. We made use of $R$ software for the econometric analysis, considering a panel data estimator for the dependent variable. The statistical effect of the considered explanators is generally confirmed and the resulting adjusted $R$-squared is relatively high.
\end{abstract}

Keywords: gravity models, trade, Western Balkans.

JEL Classification:F14, C23, C80.

\section{Facts and figures}

The annual increase of world merchandise trade volume in 2016 was 1,3\%, less than the last 20-years average of 5,3\%. This was the lowest level since the economic and financial crisis of 2008-2009. ${ }^{1}$ The negative performance of trade was a consequence of various factors, such as the decreasing import demand in developed countries, the slow import increase in developing countries and the insufficient growth of global exports.

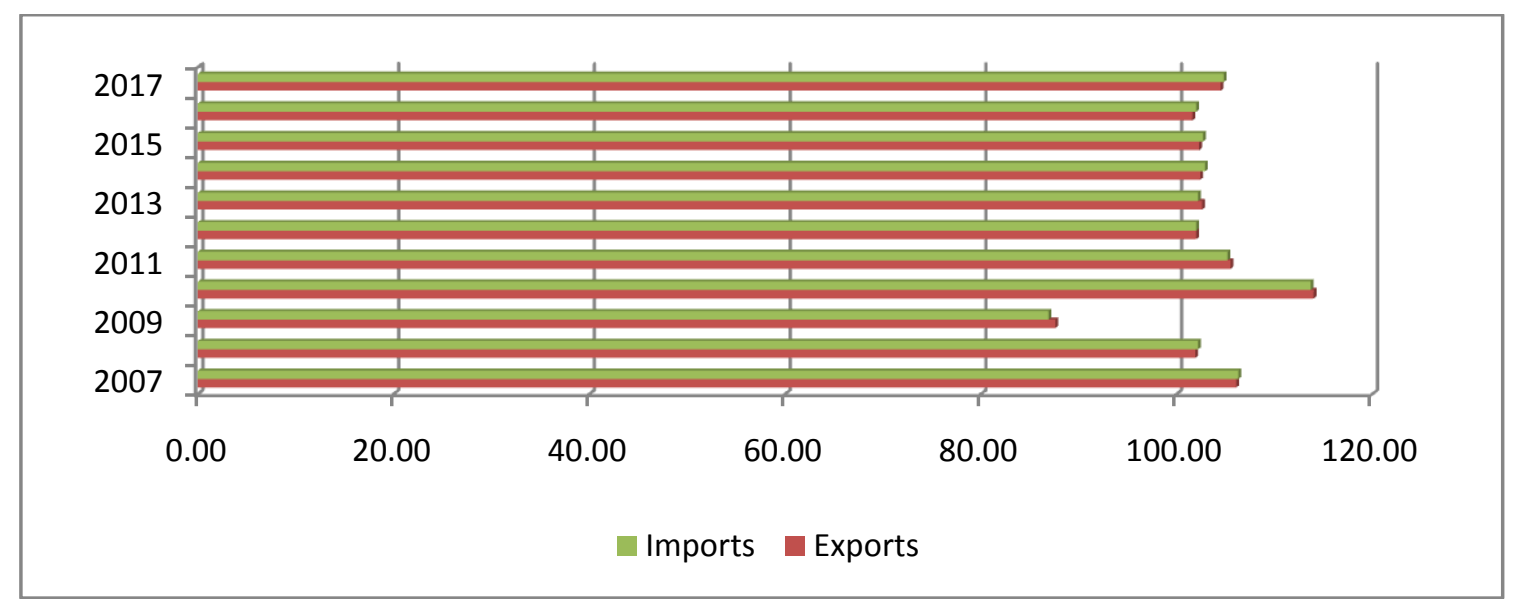

Figure 1. Annual growth rate (base: previous year $=100$ units) of world merchandise trade (imports and exports) volume for the time period 2007-2017. [Source: Author's elaboration with data from the World Trade Organization (WTO).]

\footnotetext{
${ }^{1}$ World Trade Report, 2017.
} 
The Western Balkan (WB) region is an important part of Eastern Europe. It includes Albania, the former Yugoslav Republic of Macedonia (FYROM), Bosnia and Herzegovina, Serbia, Montenegro and Kosovo. Croatia is also considered part of the region, but we excluded it from our analysis, mainly because it is a current European Union (EU) member state and it is characterized by a higher social and economic development compared to the other countries. GDP growth in 2016-2017 was below the expectations in WB countries, also due to the significant decline in commodity prices and to the low level of foreign direct investments. All WB countries ran a current account deficit in 2016. Montenegro was the country with the largest deficit $(-19,1 \%)$, while FYROM recorded the highest current account balance in the WBs $(-3,1 \%)$.

Figure 2. Current account balance (\% GDP, 2016) for Western Balkan countries. [Source: Author's elaboration on World Trade Organization (WTO) and Central Bank of the Republic of Kosovo (BQK) data.]

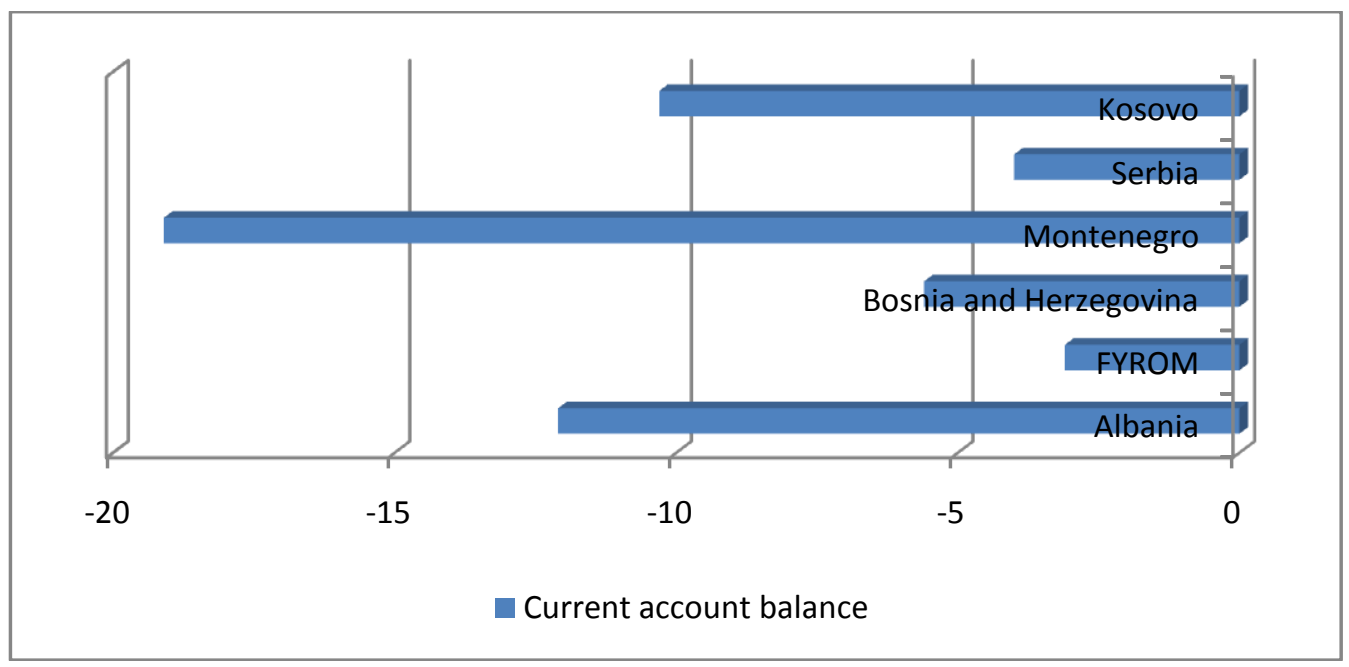

WB countries have signed several bilateral and multilateral agreements with important EU and extra-EU partners, such as the free trade agreements between Albania, Bosnia and Herzegovina, FYROM, Serbia and Turkey; Russia, Belarus and Serbia; Albania, Bosnia and Herzegovina, FYROM, Montenegro, Serbia and the EFTA countries. Croatia, Bosnia and Herzegovina, Albania, Serbia, Moldova, Montenegro, Kosovo and FYROM signed in December 2006 the Central European Free Trade Agreement (CEFTA), a trade agreement between countries that are not yet EU members. In 2007, CEFTA entered into force for all WB countries. This agreement is considered as an important step before the accession into the EU. CEFTA members commit to reduce trade barriers and to cooperate in order to intensify the bilateral exchanges of goods and services. This agreement is based on World Trade Organization (WTO) rules and procedures and on the EU regulations.

This section continues with some relevant facts and figures regarding trade and European integration of each WB country. Section 2 includes the gravity model definition, its theoretical foundation and the respective past applications. We show in the following section the gravity model estimations and other relevant empirical results. We report in section 4 some concluding remarks.

\subsection{Albania}

In June 2006, Albania signed the Interim Agreement on trade and trade-related issues and the SAA with the EU, which entered into force, respectively in December 2006 and in April 2009. The EU countries granted Albania the candidate status in June 2016. Albania has been a WTO member since 2000. Albania's main import partners are the EU and China with respectively $61 \%$ and $7 \%$ of total merchandise imports in 2016. The top export destinations of Albania are the EU and Serbia with respectively $77 \%$ and $8 \%$ of total merchandise exports in $2016 .{ }^{2}$

\subsection{Bosnia and Herzegovina}

In July 2008, the Interim Agreement on trade and trade-related issues between Bosnia and Herzegovina and the EU entered into force. In June 2012, EU and Bosnia and Herzegovina started the High-Level Dialogue on the Accession Process. The SAA between Bosnia and Herzegovina and the EU entered into force in June 2015. Bosnia and Herzegovina is continuing the accession negotiations with the WTO, after its application for membership in 1999.

\footnotetext{
${ }^{2}$ Data from the World Trade Organization (WTO), http://www.wto.org/
} 
The EU and Serbia are the largest import partners of Bosnia and Herzegovina with respectively 59\% and $10 \%$ of total merchandize imports in 2016. The EU and Serbia are also the main export destinations for Bosnia and Herzegovina with respectively $72 \%$ and $9 \%$ of total merchandize exports in $2016 .^{3}$

\subsection{Kosovo}

Kosovo is actually a potential candidate for the accession to the EU. In February 2008, the Assembly of Kosovo declared independence in an extraordinary session. In October 2015, Kosovo signed the SAA with the EU, an important incentive for the implementation of reforms. Kosovo's application and access into the WTO would provide an important stimulus for the international trade. The EU and Serbia are the largest import partners of Kosovo with respectively $43 \%$ and $15 \%$ of total merchandized imports in 2016. The main export destinations are the EU and Albania with respectively $30 \%$ and $14 \%$ of total merchandized exports in $2016 .{ }^{4}$

\subsection{FYROM}

The Agreement on trade and trade-related matters and the SAA between the EU and FYROM entered in force respectively in 2001 and in 2004. One year ahead, the European Commission accorded the candidate status to FYROM, fourteen years after the declaration of independence from Ex-Yugoslavia. In 2012, the European Commission initiated a High-Level Accession Dialogue with the FYROM authorities, which will help to accelerate public administration and electoral reforms, contribute to the protection of minorities' rights, promote market competition and encourage economic growth. FYROM joined the WTO in 2003. The main import partners are the EU and Serbia with respectively $64 \%$ and $9 \%$ of total merchandise imports in 2016. The EU and Serbia are also the top export destinations with respectively $76 \%$ and $9 \%$ of total merchandise exports in 2016.

\subsection{Montenegro}

Montenegro is an independent state since the dissolution of the Union of Serbia and Montenegro; Montenegro citizens voted for the separation from Serbia in the referendum of May 2006. After this, Montenegro reopened new accession negotiations with the EU; in 2007, the country signed the SAA, which entered into force in May 2010. In January 2008, agreements on trade and trade-related matters, visa facilitation and readmission between Montenegro and the EU entered into force. Montenegro joined the WTO in 2012. Montenegro's main import partners are the EU and Serbia with respectively $45,8 \%$ and $26,9 \%$ of total merchandise imports in 2016. The EU and Serbia are also the main export destinations of Montenegro with respectively 35,8\% and 24\% of total merchandise exports in 2016.

\subsection{Serbia}

Serbian government signed the Stabilisation and Association Agreement (SAA) and the Interim agreement on trade and trade-related issues with the EU in April 2008. These agreements are considered as important steps before the accession to the EU. The SAA between Serbia and the EU entered into force in September 2013. In January 2014, the European Council initiated the official accession negotiations with Serbia. Negotiations between WTO and Serbia are still in progress since 2004, when Serbia submitted its membership application. The EU and the Russian Federation are the largest import partners of Serbia with respectively $63 \%$ and $11 \%$ of total merchandized imports in 2016. The EU and Bosnia and Herzegovina are the main export destinations with respectively $64 \%$ and $8 \%$ of total merchandized exports in 2016.

\section{Gravity theory: theoretical foundations}

Anderson (1979) laid the foundations of the gravity theory. The author considered two countries (country i and country j) and the corresponding bilateral trade of two differentiated products. Prices are in equilibrium and preferences are assumed to be Cobb-Douglas anywhere. With frictionless trade, the respective equation is as follows.

$$
X_{i j}=b_{i} Y_{j}
$$

Where $X_{i j}$ are the exports from $i$ to $j, b_{i}$ is country $i$ 's share of expenditure on tradable goods and $Y_{j}$ is country $j$ 's income. The budget constraint is

$$
Y_{i}=b_{i} \sum_{j} Y_{j}
$$

\footnotetext{
${ }^{3}$ Data from the World Trade Organization (WTO), http://www.wto.org/.

${ }^{4}$ Data from the Kosovo Agency of Statistics (ASK), available at:

https://ask.rks-gov.net/ 
Substituting $b_{i}$ into equation (4), we obtain the following gravity equation.

$$
X_{i j}=\frac{Y_{i} Y_{j}}{\sum_{j} Y_{j}}
$$

Anderson extended the analysis, supposing that every country produces two types of goods, tradable and non-tradable, respectively. In this case, the exports from $i$ to $j$ are

$$
X_{i j}=\Phi_{j} \theta_{i} Y_{j}
$$

Where $\Phi_{j}$ is country $j$ 's share of expenditure on tradable goods and $\theta_{i}$ is country $i$ 's share of tradable goods in country $j$ 's total expenditure. The corresponding budget constraint is

$$
Y_{i} \Phi_{i}=\theta_{i} \sum_{j} Y_{j} \Phi_{j}
$$

Substituting $\theta_{i}$ into equation (7), we obtain

$$
X_{i j}=\frac{Y_{i} \Phi_{i} Y_{j} \Phi_{j}}{\sum_{j} Y_{j} \Phi_{j}}=\frac{Y_{i} \Phi_{i} Y_{j} \Phi_{j}}{\sum_{i} \sum_{j} X_{i j}}
$$

$\Phi_{i}$ Depends on country $i$ 's income and population and on other variables. We have:

$$
\Phi_{i}=F\left(Y_{i}, N_{i}\right)
$$

We can rewrite equation (9) as

$$
X_{i j}=\mathrm{A} \frac{Y_{i} F\left(Y_{i}, N_{i}\right) Y_{j} F\left(Y_{j}, N_{j}\right)}{\sum_{j} Y_{j} F\left(Y_{j}, N_{j}\right)} U_{i j}
$$

Where $A$ is a constant and $U$ is an error term that satisfies:

$$
E\left(\ln U_{i j}\right)=0
$$

Supposing that $F()$ is linear, we have that

$$
X_{i j}=\left(\frac{\mathrm{A}}{K}\right) Y_{i}^{\alpha_{1}} N_{i}^{\alpha_{2}} Y_{j}^{\beta_{1}} N_{j}^{\beta_{2}} U_{i j}
$$

Where

$$
\mathrm{K}=\sum_{j} Y_{j} F\left(Y_{j}, N_{j}\right)
$$

Applying a logarithmic transformation to equation (13), we obtain

$$
\ln X_{i j}=\ln \left(\frac{\mathrm{A}}{K}\right)+\alpha_{1} \ln Y_{i}+\alpha_{2} \ln N_{i}+\beta_{1} \ln Y_{j}+\beta_{2} \ln N_{j}+\ln U_{i j}
$$

Subsequently, Anderson considered trade barriers in the model. $\tau_{i j}$ is a transport factor and $X_{i j} \tau_{i j}$ is country $j$ 's export value from country $i$.

$$
\mathrm{X}_{\mathrm{ij}}=\frac{1}{\tau_{\mathrm{ij}}} \Phi_{\mathrm{j}} \theta_{\mathrm{i}}\left(\tau_{\mathrm{j}}\right) \mathrm{Y}_{\mathrm{j}}
$$

The corresponding budget constraint is 


$$
Y_{i} \Phi_{i}=\theta_{i}\left(\tau_{j}\right) \sum_{j} \frac{1}{\tau_{i j}} Y_{j} \Phi_{j}
$$

Substituting $\theta_{i}\left(\tau_{j}\right)$ into equation (16), we obtain

$$
X_{i j}=\frac{1}{\tau_{i j}} \Phi_{j} \frac{Y_{i} \Phi_{i}}{\sum_{j} \frac{1}{\tau_{i j}} Y_{j} \Phi_{j}} Y_{j}=D_{i j} \frac{Y_{i} \Phi_{i} \Phi_{j} Y_{j}}{\sum_{j} D_{i j} Y_{j} \Phi_{j}}
$$

Where

$$
D_{i j} \equiv \frac{1}{\tau_{i j}}
$$

Anderson also supposed that there exist two types of goods, tradable and non-tradable and every country produce multiple differentiated traded goods classified by the product class $k . X_{i j k}$ is the export volume for good $k$ from country $i$ to country $j$. We have that

$$
X_{i j k}=\frac{1}{\tau_{i j k}} \Phi_{j} \theta_{i k}\left(\tau_{j}\right) Y_{j}
$$

And

$$
X_{i j}=\sum_{k} X_{i j k}=\Phi_{j} Y_{j} \sum_{k} \frac{1}{\tau_{i j k}} \theta_{i k}\left(\tau_{j}\right)
$$

In this case, the budget constraint is

$$
Y_{i} \Phi_{i}=\left(\sum_{k} \frac{1}{\tau_{i j k}} \theta_{i k}\left(\tau_{j}\right)\right) \sum_{j} Y_{j} \Phi_{j}
$$

Supposing that transport cost depends only on distance, we have that

$$
\begin{aligned}
& X_{i j}=\left(\sum_{k} \theta_{i k}\right) \Phi_{j} Y_{j} \frac{1}{f\left(d_{i j}\right)} \\
& Y_{i} \Phi_{i}=\left(\sum_{k} \theta_{i k}\right) \sum_{j} Y_{j} \Phi_{j} \frac{1}{f\left(d_{i j}\right)}
\end{aligned}
$$

Substituting $\sum_{k} \theta_{i k}$ into equation (23), we obtain the gravity equation

$$
X_{i j}=\frac{Y_{i} \Phi_{i} \Phi_{j} Y_{j}}{\sum_{j} \Phi_{j} Y_{j}} \frac{1}{f\left(d_{i j}\right)} \quad\left[\sum_{j} \frac{Y_{j} \Phi_{j}}{\sum_{j} \Phi_{j} Y_{j}} \frac{1}{f\left(d_{i j}\right)}\right]^{-1}
$$


According to Anderson, the first term in equation (25) represents the economic distance between country $i$ and country $j$, while the second term is an indicator of the economic distance between country $i$ and the other trading partners with respect to world trade. Anderson also considered constant elasticity of substitution (CES) preferences, including prices into the share of expenditure on tradable goods function. A considerable number of authors followed similar approaches to define the gravity equation (Bergstrand, 1985; Krugman 1979, 1980; Helpman and Krugman, 1985; Helpman, 1987; Bergstrand, 1989). The number of empirical applications of the gravity model to WB trade flows is relatively low. Findings have shown the statistical significance of traditional and new variables, and unexploited trade potentials for most of the WB countries (Christie, 2002; Bussière, Fidrmuc and Schnatz, 2005; Montanari, 2005; Josheski and Apostolov, 2013; Toševska-Trpčevska and Tevdovski, 2014; Gashi, Hisarciklilar and Pugh, 2017, Reiter and Stehrer, 2018).

\section{Empirical application}

We propose a gravity equation for WB international trade flows, including basic and new independent variables. The basic gravity equation includes the economic sizes and the corresponding distance, which approximates the trade costs in our case. GDPs or GDPs per capita are common estimators of the income level and the economic development. So, let us consider the following gravity model of trade, where all variables are expressed in natural logarithm and $\varepsilon$ is an error term that follows a known distribution with a mean of zero and constant variance:

$$
\begin{aligned}
& \text { flow_odt }=\alpha_{1}+\alpha_{2}\left(g d p_{-} o t\right)+\alpha_{3}\left(g d p_{-} d t\right)+\alpha_{4}\left(d i s t_{-} o d\right)+\alpha_{5}\left(p o p_{-} s u m_{-} o d t\right) \\
& +\alpha_{6}\left(B O R D E R_{-} o d\right)+\alpha_{7}\left(F T A_{-} o d\right)+\varepsilon_{-} o d t
\end{aligned}
$$

Table 2 reports the definition and the expected sign, or the corresponding expected effect on trade flows, for each variable. Trade flows and GDPs are expressed in US dollars. We consider three possible dependent variables: import in a WB country from a given trade partner (imp_odt), export of a WB country in a given trade partner (exp_odt), and the sum of imports and exports between a WB country and the corresponding trade partner (flow_odt).

Table 2. Variables definition (expressed in natural logarithm) and expected sign.

\begin{tabular}{|l|l|c|}
\hline \multicolumn{1}{|c|}{ Variable } & \multicolumn{1}{|c|}{ Definiton } & Expected sign \\
\hline flow_odt & $\begin{array}{l}\text { Trade flow (the sum of imports and exports) between a western Balkan country }(o) \text { and } \\
\text { a partner }(d) \text { at year } t\end{array}$ & $\begin{array}{c}\text { Dependent } \\
\text { variable }\end{array}$ \\
\hline$g d p \_o t$ & GDP in country o at year t & + \\
\hline$g d p \_d t$ & GDP in country d at year t & + \\
\hline$d i s t \_o d$ & Bilateral distance & - \\
\hline $\begin{array}{l}\text { pop_sum } \\
\text { odt }\end{array}$ & Sum of populations in country o and in country d at year t \\
\hline $\begin{array}{l}\text { BORDER } \\
\text { od }\end{array}$ & Dummy variable equal to one if countries share a common border, and zero vice versa & + \\
\hline FTA_od & $\begin{array}{l}\text { Dummy variable equal to one if countries have signed a common free trade agreement, } \\
\text { and zero vice versa }\end{array}$ & + \\
\hline
\end{tabular}

We have built a dataset that includes annual trade flows between WB countries and the most important trade partners. We have considered fifteen partners for each of the six WB countries, for the time period 2010-2017. In table 3, we have listed the considered country pairs for the gravity model estimation. 
Table 3. Considered trade partners for each Western Balkan country.

\begin{tabular}{|c|c|c|c|c|c|}
\hline Albania & Bosnia Herz. & Kosovo & FYROM & Montenegro & Serbia \\
\hline Austria & Austria & Austria & Austria & Austria & Austria \\
\hline Belgium & Belgium & Belgium & Belgium & China & Belgium \\
\hline Bulgaria & Bulgaria & Bulgaria & Bulgaria & Croatia & Bosnia Herz. \\
\hline China & China & Croatia & Croatia & Denmark & China \\
\hline Croatia & Croatia & Czech Rep. & Czech Rep. & Germany & Czech Rep. \\
\hline Czech Rep. & Czech Repub. & Denmark & Denmark & Greece & France \\
\hline Denmark & Denmark & Germany & France & Hungary & Germany \\
\hline France & France & Greece & Germany & Italy & Greece \\
\hline Germany & Germany & Hungary & Greece & FYROM & Hungary \\
\hline Greece & Greece & Italy & Italy & Romania & Italy \\
\hline Italy & Italy & Romania & Romania & Russia & Romania \\
\hline FYROM & Russia & Slovenia & Serbia & Serbia & Russia \\
\hline Serbia & Slovenia & Spain & Spain & Slovenia & Slovenia \\
\hline Spain & Spain & Turkey & Turkey & Spain & Spain \\
\hline Turkey & Turkey & UK & UK & Turkey & Turkey \\
\hline
\end{tabular}

The databases of the United Nations (Comtrade) and CEPII (CHELEM-INT) were our primary sources of bilateral trade flows. GDPs and the corresponding population data were obtained by the World Bank. Bilateral distances between origin and destination countries were collected from CEPII GeoDist database (Mayer, T. and Zignago, S., 2011). Table 4 shows the main descriptive statistics for the gravity model variables.

Table 4. Main descriptive statistics for the gravity model variables.

\begin{tabular}{|l|c|c|c|c|c|c|c|c|c|}
\hline Variable & Imp & Exp & Flow & gdp_o & gdp_d & Dist & pop_sum & BORDER & FTA \\
\hline MIN & 2184083 & 8131 & 3548440 & $4,09 \mathrm{E}+09$ & $9,4 \mathrm{E}+09$ & 156 & 2623435 & 0 & 0 \\
\hline MAX & $2,7 \mathrm{E}+09$ & $2,577 \mathrm{E}+09$ & $4,89 \mathrm{E}+09$ & $4,65 \mathrm{E}+10$ & $1 \mathrm{E}+13$ & 7686,1 & $1,37 \mathrm{E}+09$ & 1 & 1 \\
\hline Mean & $3,5 \mathrm{E}+08$ & 195524404 & $5,48 \mathrm{E}+08$ & $1,59 \mathrm{E}+10$ & $1,3 \mathrm{E}+12$ & 1248,2 & 94717264 & 0,12 & 0,73 \\
\hline Median & $1,5 \mathrm{E}+08$ & 47028977 & $2,09 \mathrm{E}+08$ & $1,16 \mathrm{E}+10$ & $4,3 \mathrm{E}+11$ & 779,1 & 16333912 & 0 & 1 \\
\hline Variance & $2,23 \mathrm{E}+17$ & $1,30 \mathrm{E}+17$ & $6,15 \mathrm{E}+17$ & $1,70 \mathrm{E}+20$ & $3,63 \mathrm{E}+24$ & 2180952 & $7,52 \mathrm{E}+16$ & 0,11 & 0,2 \\
\hline Std.Deviation & $4,7 \mathrm{E}+08$ & 360772452 & $7,84 \mathrm{E}+08$ & $1,3 \mathrm{E}+10$ & $1,9 \mathrm{E}+12$ & 1476,8 & $2,74 \mathrm{E}+08$ & 0,33 & 0,44 \\
\hline Asymmetry & 2,34 & 2,97 & 2,48 & 1,4 & 2,68 & 3,49 & 4,323881 & 2,31 & $-1,1$ \\
\hline Kurtosis & 5,89 & 10,72 & 7,09 & 0,6 & 8,22 & 12,46 & 17,11251 & 3,37 & $-0,9$ \\
\hline
\end{tabular}

We report in table 6 the original output of the estimated models, obtained by the $\mathrm{R}$ software. We consider three dependent variables: imports, exports and trade flows. We considered a typical estimation method for panel data models, the random effect estimator. The random effect technique is based on the assumption that the variation between country-pairs is unsystematic and it is not correlated with the explanatory variables. In this case, we also determine the effect of variables that do not vary with time. The independent variables for the random effect estimations are statistically significant in almost all the cases. We accept the null hypothesis for the free trade agreement parameter in the trade flows and imports equations, and for the border dummy in the export equation. The adjusted R-squared varies from 60,45\% (imports equation) to 66,26\% (exports equation). Coefficients and R-squared values are comparable to previous similar studies (e.g. Montanari, 2005; Josheski and Apostolov, 2013; ToševskaTrpčevska and Tevdovski, 2014; Reiter and Stehrer, 2018). 
Table 6. Original commands for estimating the gravity model of trade and the corresponding output from $\mathbf{R}$ software. Estimation technique: Random Effects Estimator (following the 'Swamy and Arora transformation').

Dependent variables: 'flow' (sum of imports and exports), 'imp' (imports), 'exp' (exports). ['Estimate'=the value of the estimated parameter; 'Std. Error'=the standard error of the estimated parameter; ' $t$-value'=the estimated value of $t$ test for the estimated parameter; 'Pr $(>|t|) '=p$-value for the estimated parameter $]$

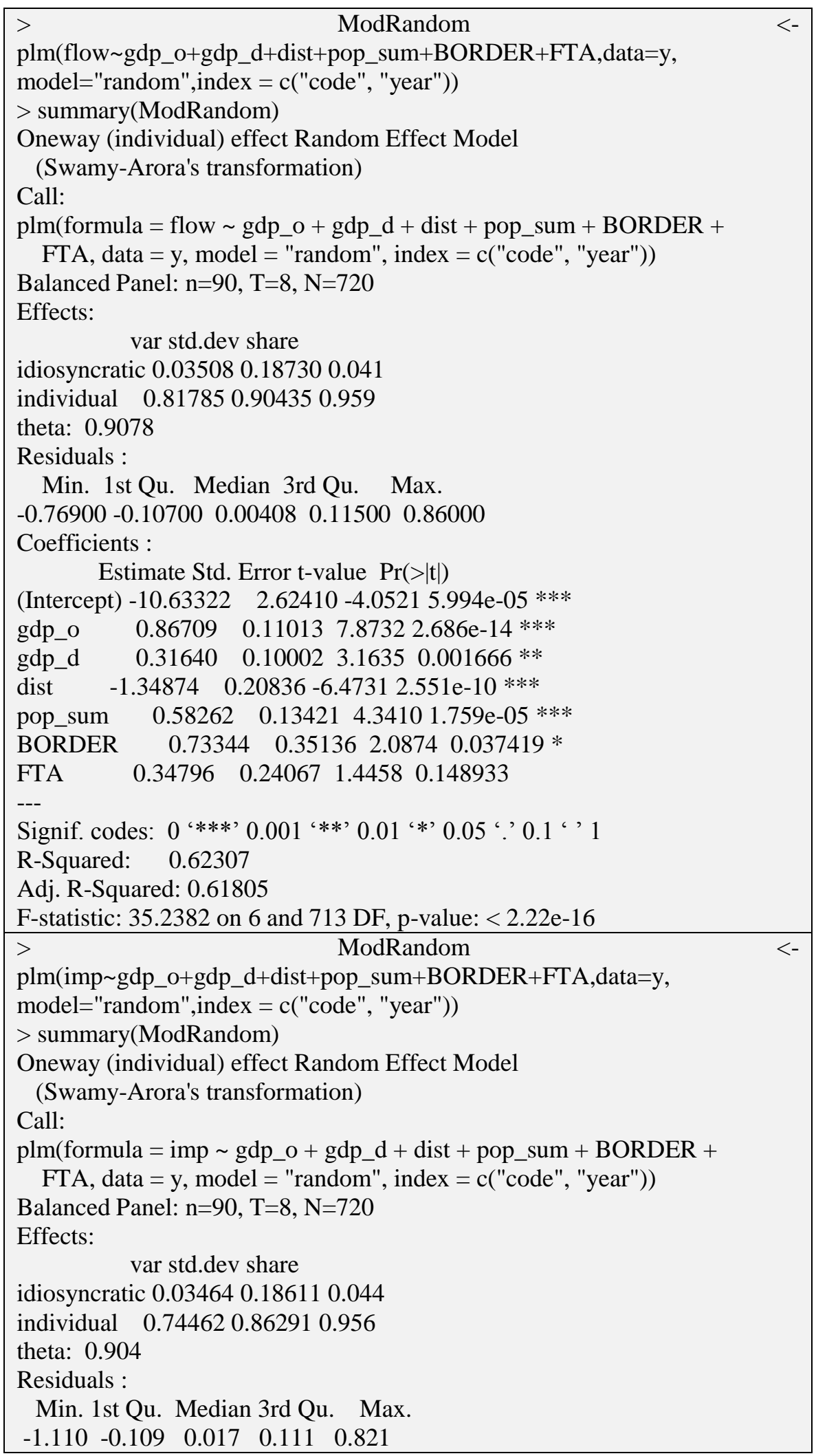




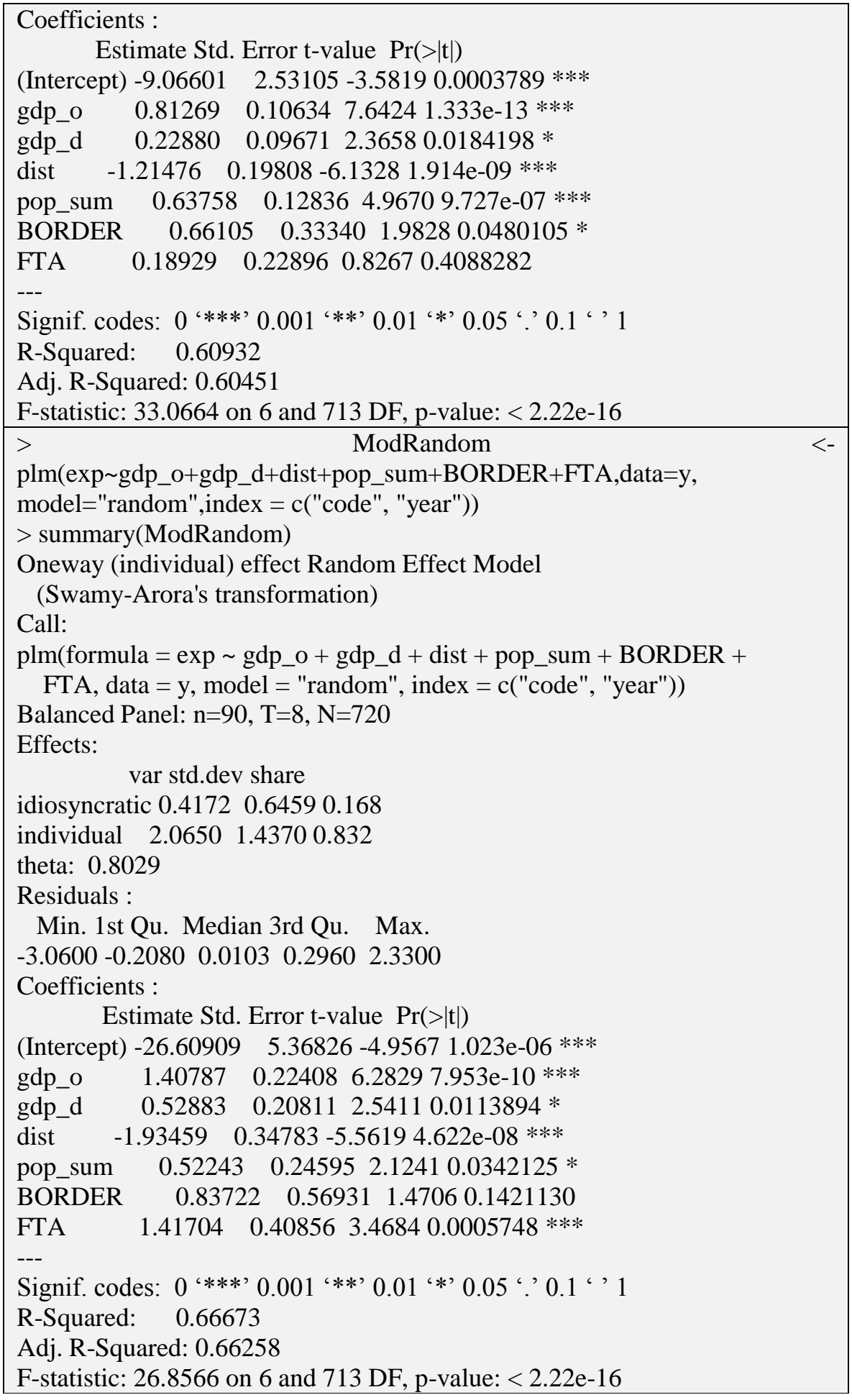

\section{Concluding remarks}

The main objective of this work was to theoretically and empirically analyze the determinants of bilateral trade between WB countries and the most important partners, through the gravity theory. Our analysis started with a summary of some relevant facts and figures regarding international trade and the corresponding determinants. During the time period 2014-2016, world trade volume suffered the worst performance since the economic and financial crisis of 2008-2009. This negative trend was a result of various factors such as the decreasing import demand in developed countries, the slow import increase in developing countries, and the insufficient growth of global exports. GDP growth in 2016-2017 was below the expectations in WB countries, also due to the significant decline in commodity prices and to the low level of foreign direct investments. 
The last part of our work was dedicated to the estimation of the gravity equations, using an appropriate dataset, which includes bilateral trade flows between WB countries and their main partners, and a set of determinants. We considered three dependent variables: imports, exports, and the sum of imports and exports. The statistical significant effect of the considered independent variables was generally confirmed. Authorities of WB countries should also orient their policies towards the technological progress, the productivity expansion, and the enhancement of business climate. A competitive environment and the reduction of trade barriers will stimulate foreign direct investments in the region.

\section{References}

Anderson, J. E. (1979). A theoretical foundation for the gravity equation. The American Economic Review, 69(1), 106116.

Bergstrand, J. H. (1985). The gravity equation in international trade: some microeconomic foundations and empirical evidence. The review of economics and statistics, 474-481.

Bergstrand, J. H. (1989). The generalized gravity equation, monopolistic competition, and the factor-proportions theory in international trade. The review of economics and statistics, 143-153.

Bussière, M., Fidrmuc, J., \& Schnatz, B. (2005). Trade integration of Central and Eastern European countries: lessons from a gravity model. Working Paper Series 0545, European Central Bank.

Christie, E. (2002). Potential trade in Southeast Europe: a gravity model approach (Vol. 21). Verein" Wiener Institut für Internationale Wirtschaftsvergleiche".

Gashi, P., Hisarciklilar, M., \& Pugh, G. (2017). Kosovo-EU trade relations: a dynamic panel poisson approach. Applied Economics, 49(27), 2642-2654.

Helpman, E. (1987). Imperfect competition and international trade: evidence from fourteen industrial countries. Journal of the Japanese and international economies, 1(1), 62-81.

Helpman, E., \& Krugman, P. R. (1985). Market structure and foreign trade: Increasing returns, imperfect competition, and the international economy. MIT press.

Josheski, D., \& Apostolov, M. (2013). Macedonia's exports and the gravity model. MPRA Paper No. 48180, July 2013.

Krugman, P. R. (1979). Increasing returns, monopolistic competition, and international trade. Journal of international Economics, 9(4), 469-479.

Krugman, P. (1980). Scale economies, product differentiation, and the pattern of trade. The American Economic Review, 70(5), 950-959.

Mayer, T., \& Zignago, S. (2011). Notes on CEPII's distances measures: The GeoDist database.

Montanari, M. (2005). EU trade with the Balkans: Large room for growth?. Eastern European Economics, 43(1), 5981.

Reiter, O., \& Stehrer, R. (2018). Trade Policies and Integration of the Western Balkans. Vienna Institute for International Economic Studies.

Toševska-Trpčevska, K., \& Tevdovski, D. (2014). Measuring the Effects of Customs and Administrative Procedures on Trade: Gravity Model for South-Eastern Europe. Croatian Economic Survey, 16(1), 109-127. 